\title{
FENOMENA KEBEBASAN BEREKSPRESI DI INSTAGRAM
}

\author{
Andhika Febi Hardina ${ }^{1}$, Firman Kurniawan ${ }^{2}$
}

\begin{abstract}
ABSTRAK
Media sosial Instagram menjadi salah satu platform yang banyak digunakan oleh masyarakat dalam kebebasan berekspresi. Namun, istilah kebebasan sendiri mendapatkan banyak persepsi sehingga banyak isu-isu yang bertentangan dengan etika dan norma. Beberapa oknum memayungi dirinya dalam sebuah kata "kebebasan". Dalam tulisan ini, penulis ingin memaparkan mengenai kebebasan berekspresi, batasan sebuah kebebasan, dan bagaimana fenomena-fenomena yang berkenaan dengan kebebasan berekspresi. Penulis menyimpulkan bahwa kebebasan ekspresi yang melewati batas secara etika dan norma, seakan membuat rasa hilang kendali dalam mengungkapkan perasaan dan pikirannya. Seharusnya msing-masing individu memiliki hak dan kewajiban penuh menggunakan media sosial secara pintar dan penuh dengan tanggung jawabnya.
\end{abstract}

Keywords: Kebebasan berpendapat, media sosial, Instagram, etika, norma

\section{ABSTRACT}

Instagram is one of the platforms that is widely used by the public for freedom of expression. However, the term freedom itself gets a lot of perceptions so that many issues are against ethics and norms. Some elements cover themselves in a word "freedom". In this paper, the author wants to explain about freedom of expression, the limits of freedom, and how the phenomena relating to freedom of expression. The author concludes that the freedom of expression that crosses the boundaries of ethics and norms, seems to make a feeling of losing control in expressing his feelings and thoughts. Each individual should have full rights and obligations to use social media intelligently and with full responsibility.

Keywords: Freedom of Expression, Social Media, Instagram, Ethics, Norms

\footnotetext{
${ }^{1}$ Departement of Communication Science, Universitas Indonesia. Email: andhika.febi@ui.ac.id

2 Departement of Communication Science, Universitas Indonesia.
} 


\section{PENDAHULUAN}

Era industri 4.0 merupakan sebuah istilah yang sudah melekat dalam kehidupan bagi masyarakat. Di seluruh negara-negara di dunia, termasuk Indonesia, perkembangan dan pertumbuhan teknologi serta informasi terjadi begitu pesat. Tidak dapat dipungkiri, pertumbuhan mengajak dan memaksa masyarakat untuk bergerak kearah yang semua semua serba digital. Termasuk media-media online seperti media sosial memiliki peran yang cukup besar untuk ikut andil dalam perubahan digitalisasi. Instagram menjadi platform yang paling sering digunakan saat ini. Hal ini dibuktikan adanya data periode bulan Januari-Mei, pengguna Instagram di Indonesia mencapai 69.270.000 juta pengguna. Data ini dirilis oleh Napoleon Cat (Goodnewsfromindonesia.id, 2020). Setiap bulannya pengguna Instagram terus meningkat. Hal ini tidak terlepas dari kebijakan Work From Home yang digaungkan pemerintah kali pertama pada Maret 2020.

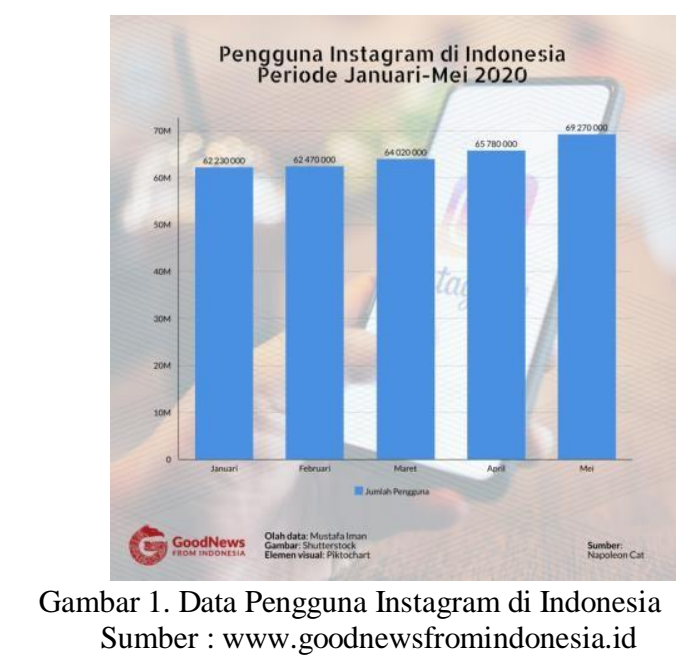

Platform Instagram menjadi idola bagi masyrakat. Dengan fitur yang lengkap, Instagram dapat digunakan untuk kepentingan perseorangan, organisasi atau korporasi, maupun sebagai media periklanan (adsense) merek dagang tertentu. Instagram digandrungi oleh milenial dengan rentang usia 18-34 tahun, didominasi kaum hawa.

Pada media sosial Instagram, pengguna mengunggah segala aktivitasnya di beranda mereka. Konten-konten yang berisikan kebebasan berpendapat dan berekspresi dapat dijumpai dengan mudah di platform ini. Aktivitas pengguna setiap harinya selalu up to date. Untuk pengguna pribadi, momen (foto dan video) yang sering diunggah adalah aktivitas sehari-hari seperti berkumpul bersama keluarga, teman, atau sekadar mengunggah kondisi disekitar mereka. Swafoto atau yang biasa disebut selfie merupakan salah satu dari banyak kegiatan yang sering diunggah.

Namun, akhir-akhir ini tidak jarang ditemukan berbagai unggahan yang dinilai tidak sesuai etika dan norma yang berlaku. Akun pribadi biasanya banyak mengunggah kehidupan pribadi yang lebih intim seperti curhat permasalahan pribadi dan rumah tangga. Atau melakukan selfie dengan sengaja menggunakan pakaian mini untuk menarik perhatian atau mendapatkan sebuah like dari para pengikutnya. Hal ini banyak dilakukan oleh perempuan. Selain itu unggahan yang mengujar kebencian secara langsung, maupun sindiran halus secara implisit pun kerap dilakukan melalui foto dan video yang diunggah di Instagram. Ini juga ditemukan dalam kolom-kolom komentar. Hal ini menjadi pemicu para pengguna lainnya melontaran kritikan, sehingga banyak tindakan ini menuai kontroversi publik. Namun, oknum-oknum tersebut selalu berdalih bahwa platform Instagram merupakan salah satu sarana untuk mengekspresikan diri. Semestinya mereka harus mengingat bahwa kebebasan sosial harus terbatas, namun pembatasnya harus dipertanggung 
jawabkan.

Unggahan foto atau video pada platform Instagram dinilai beberapa orang merupakan sarana untuk mengekspresikan diri, baik dalam perilaku dan bicara. Alasan ini selalu dipakai sebagai bentuk pembelaan jika sudah mendapatkan teguran dari beberapa pihak. Tak jarang akun-akun Instagram dengan nama samaran atau fake account mengunggah kumpulan foto dan video kontroversi dari pengguna lainnya hanya untuk mengajak pengguna lainnya memberikan komentar negatif, menertawai, serta menjadikannya sebagai bahan senda gurau. Publik menilai bahwa tindakan cari sensasi seperti itu sudah melewati batas-batas etika dan norma yang berlaku. Istilah kebebasan berekspresi dan kebebasan berpendapat menjadi payung bagi pengguna yang melewati batas-batas wajar.

Kaburnya persepsi kebebasan menimbulkan persoalan baru. Arti kata dari „kebebasan“e tersendiri disimpulkan bahwa tidak adanya batasan-batasan yang diberikan. Sehingga banyak individu mengambil tindakan sesuai dari kata kebebasan itu sendiri. Pada intinya, pertanyaan-pertanyaan mengenai kebebasan berekspresi pun muncul. Apakah sebuah kebebasan terbatas? Mengapa disebut dengan istilah „kebebasan “ jika demikian?

\section{METODOLOGI}

Pada penelitian ini menggunakan deskriptif kualitatif, dimana pada studi ini menganalisis kejadian dan fenomena kebebasan berekspresi di media sosial Instagram.

\section{ANALISIS DAN DISKUSI}

Kebebasan Berekspresi

Menurut Majelis Umum Perserikatan Bangsa-Bangsa (PBB) pada 1946, kebebasan berekspresi atau dalam istilah lain freedom of expression merupakan sebuah fundamental atas sebuah hak yang dimiliki oleh setiap individu. Dengan kata lain, kebebasan berekspresi merupakan hal dasar yang dimiliki oleh seseorang sejak ia lahir kedunia. Kebebasan berekspresi merupakan bentuk sebuah pondasi dalam Hak Asasi Manusia (HAM). Pada hakikatnya, „kebebasan " berarti dimana keadaan sesuatu yang bebas atau merdeka, dan ekspresie ${ }^{i e}$ yang merupakan bentuk sebuah ungkapan ide seseorang mengenai sesuatu. Jadi, dapat disimpulkan bahwa kebebasan berekspresi adalah suatu kemerdekaan bagi individu untuk mengungkapkan ide mengenai sesuatu.

Kebebasan berekspresi memiliki korelasi dengan kebebasan berpikir dan bagaimana menyalurkan sebuah gagasan atau ide tanpa adanya intervensi. Secara ontologis, Kebebasan berpikir tidak terikat dengan nilai, tetapi implikasi kebebasan. Sedangka secara aksiologis, letika ada pada ranah sosial dan mewujud dalam bentuk perbuatan, maka dibatasi dengan tanggungjawab dan moral (Mahfud, 2007). Kebebasan berekspresi merupakan sebuah bentuk aktualisasi diri sebagai individu sebagai satu kesatuan dalam kehidupan bermasyarakat dan cerminan dari nilai demokrasi. Dalam hal ini dibutuhkan adanya platform publik baik secara offline maupun online yang merupakan media digital, seperti media sosial dan lainnya.

Mengutip dari artikel yang diterbitkan oleh UNESCO, pada dasarnya freedom of expression 
beberapa poin utama yaitu (1) freedom of expression merupakan hal yang penting dalam menjamin pemenuhan diri dan pencapaian potensi maksimal dari individu; (2) freedom of expression sebagai alat kemajuan sebuah pengetahuan, dimana seseorang harus mendengar semua sisi pertanyaan, mempertimbangkan seluruh alternatif pertanyaan, dan menimbang kembali secara optimal; (3) freedom of expression penting agar seluruh individu dapat berpartisipasi dalam pengambilan keputusan; dan yang terakhir (4) freedom of expression berguna untuk suatu negara atau masyarakat mencapai stabilitas dan beradaptasi (Thomas Emerson, 1970).

Ketentuan freedom of expression atau kebebasan berekspresi dituangkan dalam pasal 10 (1) ketentuan freedom of expression dalam "The European Convention on Human Right" yang menyatakan bahwa kebebasan berpendapat mencakup dua dimensi, yakni pengertian dan sekaligus bentuknya. Seperti yang ditegaskan dalam pasal 19 (2) Kovenan Internasional Hak Sipil dan Politik bahwa ide-ide dan informasi dapat diterima (received) atau ditransmisikan (transmitted) secara lisan atau tulisan tercetak, dalam bentuk seni, atau melalui media lainnya yang dipiliholeh komunikan atau penerima informasi. Pada Universal Declaration of Human Rights juga sebutkan bahwa setiap orang berhak atas kebebasan pikiran, hati nurani dan agama; dalam hal ini termasuk kebebasan berganti agama atau kepercayaan, dan kebebasan untuk menyatakan agama atau kepercayaan dengan cara mengajarkannya, mempraktekkannya, melaksanakan ibadahnya dan mentaatinya, baik sendiri maupun bersama-sama dengan orang lain, di muka umum maupun sendiri.

Pada hakikatnya setiap individu memiliki hak dalam kebebasan berpikir, menyatakan pendapat, dan berekspresi. Hal ini tercantum pada Undang-Undang Dasar 1945 (UUD 1945) pada Pasal 28 E Ayat 3 yaitu "Setiap orang berhak atas kebebasan berserikat, berkumpul, dan menyatakan pendapat". Dan hal ini pun juga diterangkan pada Undang-Undang (UU) No. 39 Tahun 1999 Tentang Hak Asasi Manusia (HAM) Pasal 23 Ayat 2 "Setiap orang bebas untuk mempunyai, mengeluarkan dan menyebarluaskan pendapat sesuai hati nuraninya, secara lisan dan atau tulisan melalui media cetak maupun elektronik dengan memperhatikan nilai-nilai agama, kesusilaan, ketertiban, kepentingan umum, dan keutuhan bangsa."

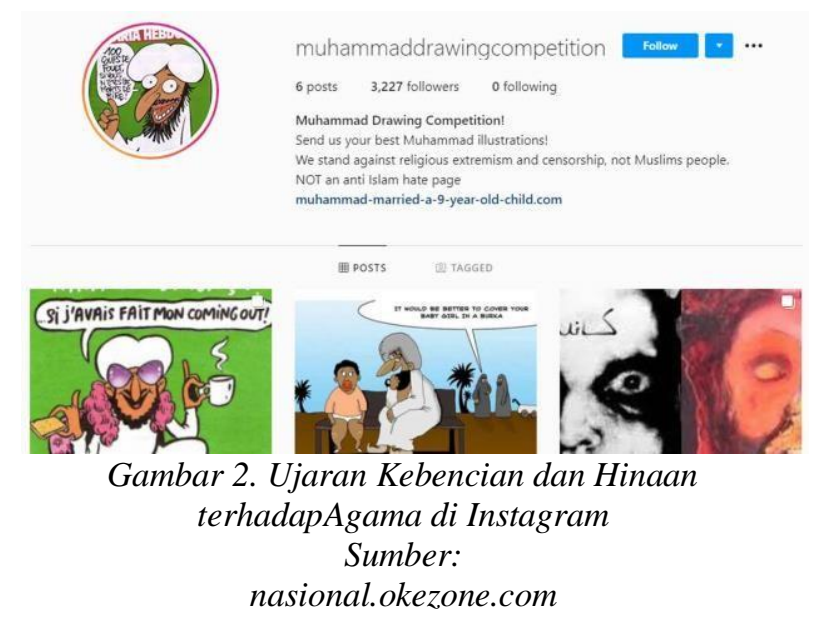

Isu-isu yang berkembang mengenai kebebasan berekspresi sangatlah kompleks. Misalnya, pada fenomena di media sosial Instagram, dimana mengunggah foto menggunakan pakaian yang kurang sopan menurut pandangan masyarakat umumnya. Ada kelompok dominan di dalam suatu suatu masyarakat melarang diekspresikannya secara umum suatu pandangan tertentu karena dinilai bertentangan dengan nilai norma sehingga menuai kritikan dan hujatan. 
Dalam hal ini, pihak yang tertindas tidak menyadari bahwa hak kebebasan berekspresi mereka sedang diabaikan. Contoh lainnya adalah unggahan foto atau video tentang

aktivitas sehari-hari. Digambarkan bahwa individu disini mengunggah sebuah video sedang berbelanja di salah satu pusat perbelanjaan yang terkenal dengan kemewahannya sambal membawa beberapa belanjaan yang telah dibelinya. Namun, para pengikutnya melabeli bahwa ia sedang memamerkan kekayaannya dengan berada di pusat perbelanjaannya, menghujatnya dengan kata-kata kasar seperti "Kok pamer banget sih!" atau merendahkannya dengan cuitan "Baru kaya ya? Baru mampu ya?". Pada kenyataannya invididu yang mengunggah video tersebut tidak ada maksud seperti komentar-komentar yang diberikan. Hanya semata-mata ingin membagikan aktitivitasnya melalui media sosial.

Selain itu, yang sering dijumpai di media sosial Instagram, dimana banyak pengguna mengunggah kehidupan mereka secara pribadi yang lebih intim. Hal ini banyak dijumpai di kalangan muda. Mereka sering mengunggah kebersamaan dengan pasangannya dengan pose yang sedikit berlebihan. Padahal mereka belum menjalin hubungan pernikahan. Namun, seolaholah seperti sudah seperti suami istri. Dan ini tidak jarang diunggah oleh banyak selebgram yang memiliki banyak pengikut. Mayoritas tanggapan publik adalah menentang dan mengkritik hal tersebut. Namun, mereka yang melakukan, membuat alasan bahwa media sosial adalah sebuah ajang kebebasan berekspresi. Sehingga mereka menganggap tidak ada yang perlu dikritik dari apa yang mereka unggah.Begitupun komentar-komentar ujaran kebencian dan caci maki, serta sumpah serapah yang disampaikan dari publik, mereka beralasan itu juga sebagai bentuk ekspresi kebebasan berpendapat. Kebebasan berpendapat merupakan sebuah keadaan yang bebas dalam mengutarakan idedan gagasannya. Namun, individu harus mampu bertanggung jawab tentang apa yang telah disampaikannya dan sesuai dengan peraturan perundang-undangan yang berlaku.

Hal ini pun menjadi dampak buruk bagi para pengguna Instagram yang masih dibawah umur untuk mencontoh perilaku-perilaku yang tidak sepatutnya untuk diiuti. Kebanyakan dari mereka memiliki pandangan bahwa hal tersebut dilumrahkan, sehingga mereka pun boleh untuk melakukannya. Arti dari sebuah konsep kebebasan berekspresi yang multipretatif dampaknya begitu signifikan, berkelanjut, dan sangat kompleks.

Walaupun seringkali dianggap sebagai dasar terciptanya sebuah demokrasi, elemen kebebasan berekspresi adalah suatu hak yang kompleks. Hal ini karena kebebasan berekspresi tidak absolut dan diiringi dengan tugas dan tanggung jawab khusus. Alasan wajib mematuhi sejumlah pembatasan yang ditetapkan oleh hukum dan diperlukan. Hak ini juga kompleks karena hak ini melindungi hak pembicara sekaligus hak pendengar. Kedua sisi hak yang sama ini kadang dapat bertentangan dan sulit untuk didamaikan. Kedua hak ini terkadang mengalami ketegangan karena tidak selalu mudah menemukan keseimbangan yang tepat antara hak atas kehormatan, keselamatan dan privasi.

Berdasarkan penggunaan data yang dikemukakan Napolean Cat yang telah dipaparkan dalam latar belakang, disebutkan bahwa ada sekitar 63,2 juta pengguna yang menggunakan media 
sosial Instagram yang mayoritas penggunanya adalah usia produktif. Hal ini penting bagi pengguna yang masihremaja untuk memilah dan memilih informasi yang sesuai dengan usia masing-masing. Sehingga walaupun lonjakan informasi yang tidak bisa

dibendung pada platform media sosial Instagram, masing-masing individu telah dapat menanamkan kepada diri sendiri mengenai pentingnya berkomunikasi dan bertanggung jawab. Individu atau masyarakat kerap menyamaratakan bagaimana berkomunikasi dengan siapapun. Dan tidak jarang individu mengekspresikannya dengan cara yang mengabaikan etika.Di Indonesia, sanksi Pasal 27 dalam UU No. 11 Tahun 2008 tentang ITE yang telah direvisi menjadi UU No. 19 Tahun 2016 pun kerap diacuhkan. Pelatihan bagaimana sebuah etika dan norma kebebasan berekspresi di ruang publik dilakukan untuk memberikan pemahaman yang benar dalam berekspresi.

Sesuai dengan peraturan perundangundangan yang berlaku, kebebasan berpendapat dituangkan dalam Undang - Undang (UU) No. 9 Tahun 1998 Pasal 6 "Warga negara yang menyampaikan pendapat di muka umum berkewajiban dan bertanggung jawab menghormati hak-hak dan kebebasan orang lain, menghormati aturan-aturan moral yang diakui umum, menaati hukum dan ketentuan peraturan perundang-undangan yang berlaku, menjaga dan menghormati keamanan dan ketertiban umum; serta menjaga persatuan ken kutuhan bangsa." Pasal 28 J Ayat 2 yang menyebutkan "Dalam menjalankan hak dan kebebasannya,setiap orang wajib tunduk kepada pembatasan yang ditetapkan dengan undang-undang dengan maksud untuk menjamin pengakuan serta penghormatan atas hak kebebasan orang lain dan untuk memenuhi tuntutan yang adil sesuai dengan pertimbangan moral, nilainilai agama, keamanan, danketertiban umum dalam suatu masyarakat demokratis." Dari beberapa pasal ini dapat ditarik kesimpulan bahwa sebuah kebebasan bereskpresi bukan semata-mata bebas dalam menyampaikan ide, gagasan, dan perasaan masing-masing individu. Namun kebebasan dalam hal ini tetap sesuai dengan peraturan-peraturan perundang-undangan yangberlaku berdasarkan etika dan norma.

Kebebasan Berekspresi dan Media Sosial

Media sosial merupakan media daring yang digunakan sebagai tempat interaksi sosial secara online di internet. Media sosial menggunakan website atau aplikasi yang mampu mengubah suatu komunikasi menjadi bentuk dialog interaktif. Menurut Kotler dan Keller dalam Aditiawarman media sosial adalah sarana bagi pengguna untuk berbagai informasi, teks, gambar, video dan audio dan dengan perusahaan dan sebaliknya (Aditiawarman dkk., 2019: 50). Instagram merupakan salah satu platform media sosial yangbanyak digunakan.

Pada apikasi media sosial Instagram pengguna dapat mengunggah foto dan video ke dalam feeds yang dapat diedit dengan berbagai filter dan diatur dengan tagar dan informasi lokasi. Unggahan dapat dibagikan secara publik atau dengan pengikut yang disetujui sebelumnya. Pengguna dapat menjelajahi konten pengguna lain berdasarkan tagar dan lokasi dan melihat konten yang sedang tren. Pengguna dapat menyukai foto serta mengikuti pengguna lain untuk menambahkan konten mereka masuk kepada beranda. Kebebasan berekspresi memainkan peran 
yang apik terhadap internet. Berdasarkan pernyataan dari pakar kebebasan berpendapat,

Dawn C. Nunziato, bahwa internet telah terkonseptualisasi sedemikian rupa menjadi semacam forum untuk kebebasan berekspresi dengan potensi nyaris tak terbatas bagi setiap individu guna mengekspresikan dirinya dan menerima ekspresi dari individu lain.

Dalam beberapa isu yang paparkan sebagai contoh, para pengguna yang kurang bertangggung jawab atas unggahan mereka. Sebelum mereka membagikannya, disini terdapat fitur, apakah publik bisa mengakses unggahan mereka atau tidak. Pengguna media sosial Instagram juga dapat mengatur akun mereka sebagai "pribadi", sehingga mengharuskan mereka menyetujui setiap permintaan pengikut baru. Jadi, bukan sebuah media yang harusnya mengatur bagaimana seseorang untuk beretika dan berperilaku, namun justru sebaliknya individu memiliki hak dan kewajiban penuh menggunakan media sosial secara pintar dan penuh dengan tanggung jawabnya.

\section{SIMPULAN}

Kebebasan berekspresi merupakan sebuah hak masing-masing indvidu yang lahir. Namun, dalam pelaksanaannya kebebasan berekspresi bukan semata-mata bebas tanpa batasan. Segala sesuatu tindakan baik secara lisan, mapun tulisan harus sesuai dengan peraturan etika berkomunikasi dan norma-norma yang berlaku. Kebebasan ekspresi yang melewati batas secara etika dan norma, seakan membuat rasa hilang kendali dalam mengungkapkan perasaan dan pikirannya. Karena mereka lupa, pada hakikatnya manusia merupakan makhluk ciptaan Tuhan yang memiliki akal dan pikiran sudah seharusnya mengedepankan akhlak ketika mengekspresikan gagasan dan perasaan.

\section{DAFTAR PUSTAKA}

Aditiawarman, Mac. dkk. (2019). "Hoax and Speech di Dunia Maya." Padang: Lembaga Kajian Aset Budaya Tonggak Tuo.

Emerson, Thomas. (1970). "The System of Freedom of Expression". New York: Random House.

Kelvin, Mikel. (2016) "Pengaturan Kebebasan Berekspresi Melalui Media Digital Menurut Hukum Internasional dan Penerapannya di Indonesia”. Universitas Hasanuddin.

Mustafa, Iman. (2020) "Pengguna Instagram di Indonesia Didominasi Wanita dan Generasi Milenial" diakses tanggal 14 Mei 2021 pukul 20.00 melalui <https://www.goodnewsfromindonesia.id /2020/06/14/pengguna-instagram-diindonesia-didominasi-wanita-dangenerasi-milenial>

\section{UNESCO. (2013) Toolkit Kebebasan} Berekspresi Bagi Aktivis Informasi. France: United Nations.

Wilson, John (2016) “The Changing Media and Academic Freedom" Journal Vol. 102. No. 1 p. 8-12. American Association of University Professors, 